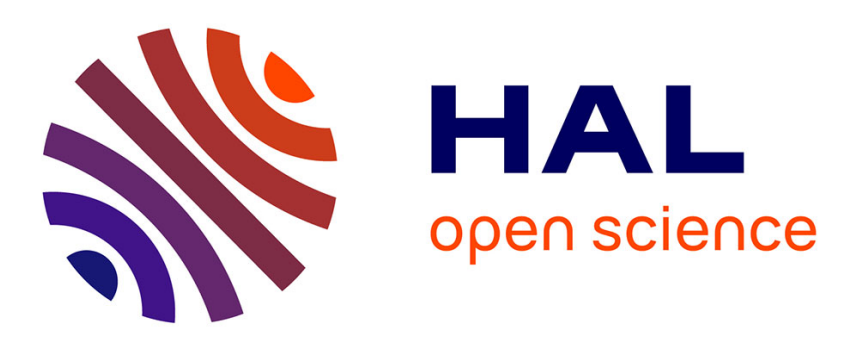

\title{
Gender, Fascism and Right-Wing in France between the wars: the Catholic matrix
}

Magali Della Sudda

\section{To cite this version:}

Magali Della Sudda. Gender, Fascism and Right-Wing in France between the wars: the Catholic matrix. Politics, Religion and Ideology, 2012, 13 (2), pp.179-195. 10.1080/21567689.2012.675706 . halshs-00992324

\section{HAL Id: halshs-00992324 \\ https://shs.hal.science/halshs-00992324}

Submitted on 23 Mar 2015

HAL is a multi-disciplinary open access archive for the deposit and dissemination of scientific research documents, whether they are published or not. The documents may come from teaching and research institutions in France or abroad, or from public or private research centers.
L'archive ouverte pluridisciplinaire HAL, est destinée au dépôt et à la diffusion de documents scientifiques de niveau recherche, publiés ou non, émanant des établissements d'enseignement et de recherche français ou étrangers, des laboratoires publics ou privés. 


\section{" Gender, Fascism and the Right-Wing in France between the Wars: The Catholic Matrix »}

M. Della Sudda, « Gender, Fascism and the Right-Wing in France between the Wars: The Catholic Matrix » Julie V. Gottlieb (Ed.) "Gender and Fascism", Totalitarian Movements and Political Religion, vol.13, issue 2, pp.179-195.

Key words: Gender; the French Far Right

\section{A French Aversion to Research into Gender and Fascism?}

While it has been some time since European historiography opened up the field of Gender and Fascism, French historiography seems to be an exception. Since the pioneering work into Nazi Germany and the Fascist regime in Italy, ${ }^{1}$ use of the gender perspective has allowed women's academic focus to shift towards other objects of study. The initial enquiries into the role of women in the politics of totalitarian regimes [180], lending their support or positioned as victims, have given way to a more diverse set of interests. ${ }^{2}$ More recent work has looked at masculinity and sexuality ${ }^{3}$, while Cultural History has been taking over research into the cultural and intellectual productions

\footnotetext{
1 See for instance V. De Grazia, How Fascism ruled Women, Italy, 1922-1945 (Berkley: University of CaliforniaPress, 1992); C. Koonz, Les Mères de la Patrie du Troisième Reich (Paris: Lieu commun, 1989); in France, L. Kandel (ed.), Féminisme et Nazisme (Paris: Odile Jacob, 2004).

${ }^{2}$ K. Passmore (ed), Women, Gender and Fascism in Europe, 1914-1945 (Manchester, Manchester University Press, 2003), see more specifically Kevin Passmore's 'introduction', pp.XI-X and « Europe », pp.235:268.

G.L. Mosse, Nationalism and Sexuality. Respectability and abnormal sexuality in modern Europe (New York: H. Fertig, 1985); M. Pollard, 'In the name of the father: male masculinities in Vichy France' in Christopher E. Forth and Bertrand Taithe (eds) French masculinities: history, culture, and politics (Basingstoke/New York: Palgrave Macmillan, 2007), pp.141-156 and J. Surkis, Sexing the Citizen: Morality and Masculinity in France, 1870-1920, (Ithaca, Cornell University Press, 2006)
} 
peculiar to these regimes or to extreme right movements. Why is it that in France, the pioneering work of Women's History into the first and second waves of feminism was not followed by work which wrestled with female political action which was more socially conservative? It is actually rare to find French academic work focussing on those forms of female activism which failed to take up the cause of women. Catholic campaigns linked to right-wing movements have drawn the attention of researchers into the Belle Époque ${ }^{4}$. In contrast, the period between the wars remains little known, with the exception of a few works such as those of Anne Cova on Catholics ${ }^{5}$, of Christine Bard on anti-feminism ${ }^{6}$ and of Francine Muel-Dreyfus on the ideological foundations of the Vichy regime ${ }^{7}$. The question of gender and fascism between the wars remains to be addressed by French scholars. How this reticence or (to borrow the terms of the debate on 'French Fascism, this 'allergy') ${ }^{8}$ to the issue of gender and fascism might be explained? An initial explanation may be found in the lack of interest which Women's History has taken in extreme-right movements and more generally, conservative ones. ${ }^{9}$ One thus finds in French historiography the same initial reticence on the part of scholars in Women's History towards working on groups hostile to feminism. However, Gender History and the methodological renewal observed in English-language historiography has still not borne fruit with French researchers regarding the issue of gender and fascism. ${ }^{10}$ It is actually only recently that the interwar period has begun to attract the

\footnotetext{
4 B. Dumons, op.cit. ; O. Sarti, Th eLigue Patriotique des Françaises. A Feminine response to the Secularization of French Society (New York/London: Garland publishing, 1992), the latest does not address the question of fascism between the wars.

5 A. Cova, Au service de l'Église, de la patrie et de la famille. Femmes catholiques et maternité sous la IIIe République (Paris/Montréal: l'Harmattan, 2000).

6 C. Bard (ed), Un siècle d'antiféminisme (Paris : Fayard, 1999).

${ }^{7}$ F. Muel-Dreyfus, Vichy et l'éternel féminin. Contribution à une sociologie politique de l'ordre des corps, (Pari : Éd. du Seuil, 1996).

8 M. Dobry (Ed.), Le Mythe de l'allergie française au fascisme (Paris : Albin Michel, 2003)

${ }^{9}$ For a very brief introduction, see. J. V. Gottlieb, 'Right-Wing Women in Women's History: A Global Perspective: Introduction' Journal of Women's History, 16:3, (2004), pp.106-107.

${ }^{10}$ J. V. Gottlieb, 'Women and British Fascism Revisited: Gender, the Far-Right, and Resistance', Journal of Women's History, 16:3, (2004), pp. 108-123; see also J.V. Gottlieb, Feminine Fascism. Women in
} 
attention of Francophone scholars addressing the issue of gender, conservatism and extreme-right movements, thus filling the gaps which separate the Belle Époque from Vichy France ${ }^{11}$.

\section{The Debate on 'French Fascism': a 'Dialogue of the Deaf'.}

One of the explanations for this absence of reflection is perhaps to be found in the thorny question of 'French Fascism'. We refer here to the hypothesis put forward by Passmore, ${ }^{12}$ that the debate on the existence, nature and extent of French Fascism between the wars considerably slowed the emergence of innovative research subjects, in particular the use of gender to grasp the mechanisms underlying the politicizations of the interwar period. ${ }^{13}$

Two major tendencies have virulently confronted each other since the 1960s. In opposition to the dominant interpretation in France proposed by the historian René Remond, who [181] sees in these movements an inheritance from Bonapartism rather than an adherence to fascism ${ }^{14}$, other historians, mainly English-speaking, have proposed analyses which have countered the theory of a French 'allergy' to fascism ${ }^{15}$. The work of Zeev Sterhell has shown that fascism was not an ideology foreign to French

\footnotetext{
Britain's Fascist Movement 1923-1945 (London: I.B. Tauris, 2003), pp.3-5.

${ }^{11}$ Regarding the Belle Epoque, B. Dumons, Les Dames de la Ligue des femmes françaises (1900-1914), (Paris : Cerf, 2006) and M. Della Sudda, "La politique malgré elles, mobilisations féminines conservatrices en France et en Italie (1900-1914)", Revue Française de Science politique, 60:1, pp.37-60. For Vichy regime, see for instance F. Muel-Dreyfus, op.cit.

${ }^{12}$ K. Passmore, 'Planting the Tricolor in the Citadels of Communism': Women's Social Action in the Croix de feu and Parti social français', The Journal of Modern History, 71:4 (1999), pp. 814-851.

${ }^{13}$ On this debate the most recent synthesis has been published in Dutch, D. Knegt, 'Ni droite, ni gauche?' Debatten over het Franse fascisme', Tijdschrift voor Geschiedenis, 124:2 (2011), 206-219; see also R. Griffin, 'Consensus? Quel consensus?' Perspectives pour une meilleure entente entre spécialistes francophones et anglophones du fascisme', Vingtième Siècle. Revue d'Histoire, $108: 4$ (2010), pp.53-69. See also, P. Burrin, 'Le Fascisme', J.-F. Sirinelli (Ed.), Histoire des droites en France, vol.1, (Paris: Gallimard, 1992), pp.603-652.

${ }^{14}$ R. Rémond, Les Droites en France (Paris : Aubier Montaigne, 1982) ; the first historian who proposed this interpretation was R. Girardet, 'Note sur l'esprit d'un fascisme français 1934-1940', Revue française de science politique, $55: 3$ (1955), pp. 529-546

${ }^{15}$ Serge Berstein proposed this interpretation on the occasion of the critical review of the work of Zeev Sternhell see S. Berstein, 'La France des années 1930 allergique au fascisme', Vingtième Siècle. Revue d'Histoire, 2:2 (1984) pp.83-94.
} 
political culture, but one of its manifestations issuing from an intellectual substratum with its origins on the left ${ }^{16}$. At the same time, Robert Soucy, as well as William D. Irvine, defended the idea that one can see in the extreme right-wing leagues a set of characteristics which were common both to the Italian Fascist party and these movements which were calling for a dictatorship ${ }^{17}$. In political science, M. Dobry and other scholars proposed a sociological critique to the immunity thesis based on a sociological perspective using the conceptual frameworks of P.Bourdieu. ${ }^{18}$

The case of the Croix de Feu, an ex-servicemen's organization which took part in the 6 February 1934 riots, is the main controversial point in discussions between specialists ${ }^{19}$. The outcome has been that today Anglophone historians and French political science scholars consider the thesis of a 'French immunity' to be untenable. ${ }^{20}$ Recently, the conference on 'French Right-Wing between the Wars: Political and intellectual movements. From conservatism to fascism' ('Les droites françaises de l'entre-deux-guerres: mouvements politiques et intellectuels. Du conservatisme au fascisme') held in Paris in 2008 provided an opportunity for these researchers to consolidate this consensual vision around the existence of a French fascism extending well beyond those small groups which referred explicitly to the Italian PNF party and which in fact included the Croix de Feu. The same year, Historical Reflections devoted a great deal of space to this

\footnotetext{
${ }^{16}$ Zeev Sternhell, Ni droite, ni gauche. L'idéologie fasciste en France (Paris : Seuil, 1983) transl. Neither Right nor Left: Fascist Ideology in France, (Princeton: Princeton University Press, 1995).

${ }^{17}$ R. Soucy, 'Fascism and the Croix de Feu: A Dissenting Interpretation', Journal of Contemporary History, 26:1 (1991), pp. 159-188; W. D. Irvine, 'Fascism in France and the Strange Case of the Croix de Feu,' The Journal of Modern History 63:2 (June 1991), pp. 271-295

${ }^{18}$ Dobry, ibid.

${ }^{19}$ R. Soucy, Fascisme français ? 1933-1939, mouvements antidémocratiques, (Paris : Autrement, 2004) ; transl. Francine Chase \& Jennifer Phillips, French Fascism: The Second Wave, 1933-1939, (New Haven : Yale, 1995); Kevin Passmore endorses this point of view but is less assertive regarding the Parti Social Français, K. Passmore, From Liberalism to Fascism. The Right in a French Province 1928-1939 (Cambridge: Cambridge, 1997).

${ }^{20}$ S. Kennedy, 'The End of Immunity? Recent Work on the Far Right in Interwar France', Historical Reflections, 34:2 (2008), pp. 25-45.
} 
interpretation while attempting to escape from the polemic. ${ }^{21}$ Gender took a prominent place in this, offering a glimpse of the new areas opened - such as masculinity, women's suffrage - up by these Anglophone historians, following the pioneering works of Passmore and Koos and Sarnoff'22.

Despite this, the majority of French historians still emphasize the marginal character of these political experiments. In their view, fascism was only represented in France by groups and organization which explicitly asserted their fascist nature, such as Antoine Rédier's Légion, Georges Gressent-Valois' Faisceau, Marcel Bucard's Francisme and Jacques Doriot's Parti populaire français (PPF), which resorted to political violence and displayed a very clear preference for the Italian dictatorship and for corporatism. ${ }^{23}$ [182] According to this interpretive framework, the Croix de Feu, the war veterans' organization with the Death's Head insignia, which was to take on a paramilitary dimension after 1933, was simply an authoritarian right-wing mass organization. In a recent issue, the French journal Vingtième Siècle devoted a great deal of space to the issue of French Fascism and to this polemic. ${ }^{24}$

In this debate, gender issue was either never or very marginally addressed by Frenchspeaking male historians. ${ }^{25}$ While emphasizing the virile ideal upheld by fascism, most participants in the debate denied the relevance of gender and its usefulness as an analytical tool in the interpretation of the movements which they were studying. The assumption that women became a subject of political history only when they had the

\footnotetext{
${ }^{21}$ Historical Reflections, 34:2 (2008).

${ }^{22}$ C.Koos \& D. Sarnoff, "France", in Passmore (Eds.) Women, Gender, op.cit. pp.168-188.

${ }^{23}$ P. Milza, Fascismes français. Passé et Présent (Paris : Flammarion, 1987) p.14-15. More recently the historical review Vingtième Siècle published several articles revealing the persistence of the cleavage between French speaking historians who follow René Rémond's interpretation and those who follow Robert Soucy.

${ }^{24}$ Vingtième Siècle. Revue d'Histoire, 95:3 (2007), pp.219-246.

${ }^{25} \mathrm{As} \mathrm{F}$. Thébaud noticed, the late feminization of the historical profession is one of the reason of the difficulty to introduce Women and then Gender History in France, see F. Thébaud, Ecrire l'histoire des femmes et du genre (Lyon:ENS, 2009).
} 
right to vote lies at the heart of the gender blindness as well as epistemological assumptions pointed by Kevin Passmore in his article on Gender and Political Religion. ${ }^{26}$ Political religion theories are rooted in sociological and psychoanalytical traditions that gives few room for taking into account women's agency. Considering the dichotomy between the charismatic elite - implicitly masculine - and the manipulated mass - considered as passive i.e. feminine - this approach failed to provide a complex understanding of women's militancy within the extreme-right and their major role within the Fascist State once these parties were ruling Italy or Germany. What we would like to argue here, is that women's involvement in fascist or extreme right movement - whatever historians calls the leagues of the Interwar - has to be understood more as the result of an incremental process: the result of long-term mobilization in conservative organizations who eventually provided strong support for the Vichy regime. ${ }^{27}$ Now, it would appear that the shift of focus onto the activity of these groups, their organization, their positioning as regards central questions for democracy such as women's voting rights and citizenship would enable an avoidance of the French Fascism controversy, as Passmore emphasized in his pioneering article. ${ }^{28}$

\section{French extreme-right and the fascist leagues between the wars}

In contrast to the case of the German, the Italian case or theUnited Kingdom where the British Union of Fascists had a hegemonic position, in France various groups designated themselves as fascist or were described as such by contemporary observers such as the Communist Party or the Socialist SFIO (Section française de l'internationale socialiste), State Security (Sûreté générale) officers responsible for the surveillance of political parties. Until

\footnotetext{
${ }^{26}$ Kevin Passmore, 'The Gendered Genealogy of Political Religions Theory', Gender \& History, 20:3 (2008), pp. 644-668.

${ }^{27} \mathrm{~F}$. Muel-Dreyfus acknowleged the role played by Catholic movements in her essay on Vichy within a bourdieusian sociological framework, F. Muel-Dreyfus, ibid.

${ }^{28}$ K. Passmore, 'Planting the Tricolore in the Citadels of Communism', op.cit., p. 815.
} 
the dramatic circumstances of June 1940, they failed to build a unified movement around a charismatic leader who could possibly mobilize the population to take the power. One explanation could be found in the disbandment of the fascist organizations after the riots and then the arrival of the Popular Front into power (1936). The structure of the political competition could also explain the failure to overcome divisions amongst those movements.

A first series of groups opposed to the parliamentary Republic was founded as a reaction to the election of the Cartel des gauches Coalition of the Left in 1924. These mainly comprised the Faisceau led by Georges Gressent (also known as Valois), by the Feunesses [183] Patriotes (Patriotic Youth, JP) founded and presided over by the businessman and champagne magnate Pierre Taittinger as well as the small group which was the Légion, part of which quickly joined the feunesses patriotes. The ephemeral nature of the Légion, which was active between 1924 and 1927, did not prevent the dissemination of the ideas championed by its leader ${ }^{29}$. The moderate right-wing legislature which followed it from 1928 to 1932 saw fascist organizations losing ground: the Faisceau went out of existence for lack of money and members, and these movements failed to attract memberships more than a few tens of thousands strong. In contrast, the following period, marked by the coming to power of the moderate left in 1932, and then the Popular Front (Front populaire) with Communist support in 1936, saw the apogee of extreme right-wing leagues in the 1930s. In 1933 the Croix de Feu instituted a National Volunteers (Volontaires nationaux) section and took on a more strongly-marked paramilitary character. In the spring of that year the perfumer François Coty, who had strongly financed the nationalist press and the JP, founded his own movement, Solidarité française (French Solidarity). The movement reached its apogee with the events of 6 February 1934 only

\footnotetext{
${ }^{29}$ C. Koos, 'Fascism, Fatherhood and Family in Interwar France. The Case of Antoine Rédier and the Légion', Journal of Family History, 24:1 (1999), pp.317-329.
} 
to disband in the autumn following Coty's death. Finally, in 1933, the war veteran Marcel Bucard, who had taken part in the Faisceau, declared the creation of the Francisme group together with other former servicemen under the Arc de Triomphe.

All these groups took part in the riots of 6 February $1934 .{ }^{30}$ Following a financial scandal, the organizations marched on the National Assembly, with the proclaimed aim of overthrowing the parliamentary regime. However, at the last moment, some groups such as the Croix de Feu failed to take part in the final assault. Nonetheless, the clashes left 15 dead and more than 1400 injured. According to the police, among the extreme-right wing leagues present were Action française which then had 60,000 members, the Croix de Feu which claimed 100,000 members, Jeunesses patriotes with an estimated 94,000, Solidarité française with strength of 180,000 and the small Franciste party with 1500 members ${ }^{31}$. The extreme-right leagues did not take the Assembly and overthrow the regime.

\section{Gender, Women, and Right-Wing Political Activity in France between the Wars}

The use of gender as an analytical tool in our view enables us to avoid the impasse of the polemic around the issue of French fascism, not only by shifting the focus onto littleknown protagonists of the history of these movements, analysing their role, motivations and political engagement and also look onto the gendered political representations which underpinned the ideology of the various right-wing leagues between the wars. In

\footnotetext{
${ }^{30}$ In addition to these movements there were other groups which will not be studied here, the Green Shirts (Chemises vertes) led by Henri Dorgère, the Agrarian Party (Parti agraire), both of which focussed on rural areas, and Action française, a monarchist league founded at the time of the Dreyfus Affair, and whose influence remained strong despite competition from the other organizations.

${ }^{31} \mathrm{M}$. Amat, Rapport général fait au nom de la Commission d'enquête chargée de recherche les causes et les origines des événements du 6 février 1934, (Paris: Chambre des Députés, 1934), cited by R. Soucy, 'Fascismes français', op.cit.p.73.
} 
contrast to the pessimistic position adopted by Geoff Read, ${ }^{32}$ who emphasizes the absent of Francophone general work on gender during the interwar period in France, a significant French-language literature exists for this period concerning feminist and female movements and more [184] generally the social, economic and cultural transformations which emerged from the War. ${ }^{33}$ In contrast, the observation remains true for work in History of Politics and more exactly for studies of right-wing conservative, extreme-right and fascist movements.

On the contrary, English-language literature on this topic is rather flourishing. Numerically the most significant (and most recent) works address Cultural History. The expression of power relations and the formulation of an ideal of femininity and masculinity in the literature of extreme-right movements are the issues which have attracted the attention of researchers working along the lines of the definition proposed by Joan Scott. ${ }^{34}$ Mary Jean Green has studied the publications of a member of the Croix de Feu, Marie-Thérèse Delahaye-de Marnyhac (1875-1962), known as Trilby. ${ }^{35}$ This author already had a past as a writer behind her when she placed her pen at the service of the Croix de Feu, and was to continue her career as an author of children's books, with her militant activism being largely passed over in silence by reviews of her work. ${ }^{36}$ Of aristocratic origins, she lived in Neuilly, the select residential area of Paris. The novels published by T. Trilby were addressed to a wide, mainly middle-class public which was

\footnotetext{
${ }^{32}$ G. Read, 'Des hommes et des citoyens: Paternalism and Masculinity on the Republican Right in Interwar France, 1919-1939', Historical Reflections, 34:2 (2008), pp.88-111.

${ }^{33}$ For example F. Thébaud, Quand nos grands-mères donnaient la vie. La maternité en France dans l'entre-deux guerres (Lyon : Presses universitaires de Lyon, 1986) ; C. Bard, Les Filles de Marianne. Histoire des féminismes, 1914-1940 (Paris: Fayard, 1995).

${ }^{34}$ J.W. Scott, 'Gender: A Useful Category of Historical Analysis', The American Historical Review, 91:5 (1986), pp.1053-1075.

${ }^{35}$ M.J. Green, 'The Bouboule Novels: Constructing a French fascist Woman', Melanie Hawthorne, Richard J. Golsan, eds. Gender and Fascism in Modern France (Hanover: University Press of New England, 1997), pp.49-68.

${ }^{36}$ The most reliable source consulted to date is the French SUDOC site which references authors: http://www.idref.fr/028256573.
} 
the central target of the Croix de Feu after 1933. They show a female character, Bouboule, who joins the Croix de Feu and finds herself caught between the movement's directives and her own militant aspirations. Green emphasizes the tension between on the one hand women's assignation to a role as a producer and reproducer of the nation through motherhood, and on the other hand the heroine's desire to be politically active in the Croix de Feu, reverting to her maiden name and clearly choosing the status of celibacy. This opposition is confirmed by a reading of the 'Women's pages' of Flambeau (Torch), the publication outlet of the Croix de Feu. ${ }^{37}$ Marginalized within the organization, women who take up a place in the hierarchy of the Croix de Feu, like Bouboule, do not match up with the model expected for Frenchwomen as a whole.

Far from being a contradiction, this articulation stems from a characteristic of conservative women's organizations inspired by Catholicism. ${ }^{38}$ In fact it fits into a vision of the social order which is non-egalitarian and hierarchical, not only as regards gender and social class but also as regards relations between elite and masses. Exactly as occurred in Catholic women's movements, one finds the Croix de Feu calling upon all women to bear children, including those who were not mothers of families. ${ }^{39}$ No surprise then, that Trilby is cited as one of the most read novelist by the Catholic women involved in the Ligue feminine d'Action catholique française, the most powerful organization of the century with almost 1.8 million members at this time. In a [185] survey about the press led in 1932-1932, 2\% of the answers (429 response on 20000 ) mentioned Trilby. ${ }^{40}$ According to the survey, the youth organization answered more

\footnotetext{
${ }^{37}$ M.J. Green, 'Gender Fascism and the Croix de Feu: the Women pages of Le Flambeau', French Cultural Studies, 8, (1997), pp.229-239.

${ }^{38}$ M. Della Sudda, 'Discours conservateurs, pratiques novatrices', Sociétés et représentations, 24:2 (2007), pp.224-231.

${ }^{39}$ S. Kalman, The Extreme Right in Interwar France: The Faisceau and the Croix de Feu (Burlington: Ashgate, 2008), pp. 111-114; K. Passmore, 'Planting the Tricolore in the Citadels of Communism', p.838. ${ }^{40}$ A. de Parvillez, 'Que lisez-vous. Réponse de 20000 Françaises', Echo de la Ligue féminine d'Action catholique française, February 1934, p.37.
} 
significantly that the adult branch $(5 \%$ of the youth organization took part to the survey). This might suggest that beside the traditional catholic hagiography proposed to the activist, the female characters of Trilby's novel could be a relevant model for catholic women involved in this organization. ${ }^{41}$ As the catholic league's bulletin stated, the female readers "are looking for help, a way to know their lives and their duties". ${ }^{42}$ They thus share a common 'political' culture with the Croix de Feu conveyed by the novels and the papers, which were available in each local committee of the LFACF though an itinerant library loan service held by Catholic women activists.

Similarly to the observations made by Daniella Sarnoff, gender has a central position in the speeches made by the far-right leagues and the catholic ones. As Sarnoff has shown, Motherhood is a social function in the political edifice of extreme right-wing leagues. She sees in these movements the representatives of a French fascism which shares in the assignation of women to procreation, in the vision of the social world based on the family, the basic unit of society, and on the sexual hierarchy ${ }^{43}$. However, for the Catholics, a fundamental distinction is made between those women who will become mothers through the flesh and those who will be spiritual mothers. ${ }^{44}$ Emancipated from biological motherhood, this elite was supposed to take up guiding positions in movement. In so doing, they embrace an independent and 'virile' femininity closed attractiveness apart - to what was expected from women in fascist organizations

\footnotetext{
${ }^{41}$ The answers also show that women are reading this book to find instruction and models in their everyday life.

42 A. de Parvillez, 'Que lisez-vous. Réponse de 20000 Françaises (suite)', Echo de la Ligue féminine d'Action catholique française, March 1934, pp.33-34.

${ }^{43}$ D. Sarnoff, 'In the Cervix of the Nation: Women in French Fascism 1919-1939' (Ph.D Dissertation, Boston College, 2001), pp. 64-111.

${ }^{44}$ M. Della Sudda, 'From the Angel of the Household to the Apostles of the 20th Century', in P. Pasture,

T. Van Osselaer (Eds.), Households of Faith (Leuven, KUP, 2012).
} 
abroad. ${ }^{45}$ Virility is understood here as an attribute shared by men and women, one synonymous with courage and strength. ${ }^{46}$

In this sense there is much more of continuity between fascist movements and conservative Catholic women's league, than a gap with the models of womanhood proposed by these movement. This continuity between the various right-wing and far right women's movements is also emphasized by Geoff Read who wonders whether there existed a 'fascist femininity' such as the one observed in other countries - German and Italy, and to a lesser extend within the British Union of Fascists - in the various extreme right-wing organizations during the interwar period. ${ }^{47}$ Fascist femininity in these cases is characterized by a traditional conception of motherhood as a political and natural duty for women but, in contrast to conservative femininity, women are also encouraged to be attractive, and even for a minority, to engage in street-fighting against the enemies of the Nation or the race. Looking closer to the gender models offered by the French Socialist Party, the Radical and Radical-Socialist Party, the conservative Alliance démocratique, the Christian Democrat Parti démocrate populaire, the catholic Fédération républicaine, the Croix de feu/Parti social français, and the Parti populaire français, Read finds a continuity in terms of gender ideology and femininity ${ }^{48}$.

[186] Using gender as an analytical tool has not only enabled researchers to bring out the complex development of models of femininity within the leagues. The definition of norms of masculinity within right-wing movements between the wars has been subjected to an innovative approach. In her work on Antoine Rédier, the founder of the Légion,

\footnotetext{
${ }^{45}$ J. Gottlieb, Feminine Fascism, op.cit.pp.94-112. Although Catholics did not embrace the violence at the heart of the mal youth gang model as some PNF members or BUF members did.

${ }^{46}$ This meaning is used in the writings of Catholic women's associations to refer to female activists and women with a vocation to regenerate society. It thus constitutes a break with the etymology of the word with its masculine reference. See Dictionnaire historique de la langue française, (Paris: Robert, 1992), pp.2263.

${ }^{47}$ G. Read, 'Was There a Fascist Femininity? Gender and Fascism in Political Context', Les Droites françaises dans l'entre-deux-guerres, 2008, Paris.

${ }^{48}$ Read, ibid.
} 
Cheryl Koos sheds light on its founder's patriarchal political project based on fatherhood and the head of the family as the central figure of political authority ${ }^{49}$. For his part Geoff Read, taking masculinity as his means of approach, rephrases the debate on fascism in a particularly convincing manner. Indeed, if fascist ideology was essentially based on the construction of a new man and on hyper-masculinity, should we not look for an answer to the question of French Fascism in the representations proposed by these leagues? Read points out the close relationship between the Croix de Feu and other, more moderate conservative political formations linked to the Church: the stress laid on fatherhood and on patriotism was largely shared by other formations. In contrast, the uniqueness of the Croix de Feu lies in a hyper-masculinisation of youth, a 'militarised masculinity', unthinkable in more traditional conservative circles. ${ }^{50} \mathrm{He}$ also sees in the cult of the dead and of martyrdom strong similarities with National Fascist Party in Italy. This author accordingly concludes that the Croix de Feu was in fact a French Fascist movement from this perspective.

The gendered division of political labour within conservative and extremeright movement: continuity with the pre-war period and similarities

The work of these historians has made significant contributions towards our understanding of gender in the general economy of the power relations characterising the ideology of the various extreme-right movements. In contrast, very few have provided concrete information on activism within these organizations, except for Kevin Passmore's currently indispensable article on feminist activism in the Croix de Feu and the social sections of the Parti social français. ${ }^{51}$ The sexual organization of political work, often

\footnotetext{
${ }^{49}$ C. Koos, 'Fascism, Fatherhood and Family in Interwar France', op.cit., see also Koos\&Sarnoff, op.cit, pp.170-176.

${ }^{50}$ G. Read, 'Des Hommes et des citoyens: Paternalism and Masculinity on the Republican Right in Interwar France, 1919-1939', Historical Reflections, 34:2 (2008), pp. 88-111.

${ }^{51} \mathrm{~K}$. Passmore, 'Planting the Tricolor in the Citadels of Communism': Women's Social Action in the
} 
discussed in general terms following the prescriptions we see in the printed publications, leaflets, and propaganda put out by the movements, remains an obscure matter within the historiography of gender.

From a methodological point of view, understanding this question requires the availability of archives which are rich enough to show the daily functioning of these organizations and their transformation. In France, most of these records show gaps. State Security (Sureté générale) archives are often inexplicit as regards the presence of women. The organizations themselves very often failed to preserve records after their disbandment. No search for their testimony was carried out when these women activists were still alive, in contrast to what happened in the United Kingdom or in other countries. ${ }^{52}$ Finally, private and family records remain difficult to access and require lengthy research which the constraints of the academic world make difficult to carry out. The main sources available to researchers are thus the records deposited at the Sciences Po History Centre and those in the French National Archives, which contain surveillance reports on the leagues and on extreme right-wing organizations. Other complementary sources can also provide information on female activists who had responsibilities at national level, For example, the National Union for Women's Suffrage (Union nationale pour le vote des femmes, UNVF), [187] the Catholic association founded in 1920 to call for votes for women in order to ensure the conformity of earthly laws with Catholic principles, included women activists from other organizations such as the Feunesses Patriotes. One can thus both reconstruct the activist "careers" of individuals and understand the systemic functioning of extreme-right and other female organizations. The archives of the Catholic Church - not only the Archives of the Archbishoprics, Archives of the Cardinals' and Bishops' Conference, but also the Vatican Secret 
Archives - can also provide us with information on the political careers of female activists and heads of section.

On the basis of the archives consulted during previous researches and of the work carried out by Anglophone researchers, this last section brings out the way in which gender legitimated and structured the division of political labour. Three organizations constitute three different examples of the way in which gender structured female activism and shapes the right and extreme-right movements.

The Faisceau, a Self-Declared Fascist Organization and the Failure of Female Mobilization.

On 10 February 1926, in the Salle Wagram in Paris, the Faisceau held a public meeting. Its leader, Georges Valois congratulated himself on having tried 'to obtain the approval of French women' and believed he had received it, something that 'augured well for the future'. ${ }^{53}$ On this date, the Faisceau claimed 20,000 members and 200,000 potential members, though this was far from the reality. ${ }^{54}$ This mention of women is so rare in reports on the movement that it invites us to reflect on the way in which gender structured this association. The Faisceau was founded with a view to preparing men to act against any revolution which the Left might have brought about in the wake of its election in 1924. The movement addressed itself firstly and primarily to war veterans and young males. Georges Valois' political project was to establish a corporatist State which was ready to fight (Etat Combattant), in which power would be conferred by the charismatic "Leader". His vision of authority and power shares the assumption that masculinity is one of the element of the political charisma. ${ }^{55}$ Kalman has rigorously

\footnotetext{
53 Anonymous, typescript report, Paris, 11 February 1926, Centre d'accueil et de recherche des archives nationales (CARAN), AN F7 13210.

${ }^{54}$ S. Kalman, The Extreme Right in interwar France: The Faisceau and the Croix de Feu (Burlington: Ashgate, 2008).

${ }^{55}$ K. Passmore, 'The Gendered Genealogy of Political Religions Theory', Gender \& History, 20:3 (2008),
} 
studied the manner in which the Faisceau positioned itself in relation to the 'women's question' between the wars. In his view, the Faisceau was divided over the role which women should play and over the way in which femininity should be incarnated.

Although Valois never alluded to women issues in his political project, several representations emerge from a reading of Nouveau Siècle ('New Century') and Faisceau documents. ${ }^{56}$ On the one hand, a vision congruent with Georges Valois' modernising aspirations can be seen on the front page of Nouveau siècle. Whether referring to the tennis champion, Suzanne Lenglen, or the first woman surgeon, $\mathbf{M}^{\mathrm{me}}$ Briand-Garfield, 'Women were simply cast as modern professionals at the top of their chosen field' ${ }^{57}$ Articles by $\mathrm{M}^{\mathrm{me}}$ Claude Aragonnès, cousin of a famous jesuit, also pleaded for equal access for women to the professions and to higher education. Nonetheless, the primary mission of women remained motherhood. As Claude Aragonnès wrote in her Nouveau Siècle, column, 'Nature and common sense, and the unanimous opinion of husbands, demand that the housewife thinks of the family first and foremost'. ${ }^{58}$ Notably more conservative and hostile to any [188] idea of civil or professional equality, other columnists in the Nouveau Siècle, such as the Catholic publicist Gaëtan Bernoville, denounced feminism and proposed a nature-based vision of sexual difference which conformed with Catholic doctrine.

From an organizational point of view, in reality women were marginal within the Faisceau. As Kalman states, confirming Sarnoff's analysis, 'Valois and his colleagues rarely consulted members of the Faisceau Féminin, which had no active voice in the group's decision-making process. Their sole outlet was the irregular Pages de la famille

pp.652:653; E. Varikas, "Max Weber, la cage d'acier et les dames", in V. Descoutures et al. (Eds), Sous les sciences sociales, le genre (Paris: La Découverte, 2010), pp.

${ }^{56}$ S. Kalman, The Extreme Right in Interwar France, op.cit., pp.112-113.

${ }^{57}$ S. Kalman, The Extreme Right in Interwar France, op.cit. p.115.

${ }^{58}$ C. Aragonnès, 'L'Activité féminine', Nouveau Siècle, 14 Sept ; 1926, quoted by S. Kalman, The Extreme Right in Interwar France, op.cit p.118. 
('Family Pages') in the group's daily newspaper, which discussed cooking, recipes and children's games rather than political or social issues'. ${ }^{59}$ In the initial founding leaflet of 11 November 1925, women could join the Friends of the Legions (Amis des légions) ${ }^{60}$. They were thus not authorized to take part in the movement. Later, they were admitted to the 'Civic Section' (Section civique) along with those Frenchmen who could not or would not take part in the first three sections. The following table summarizes the qualities required of women and the cost of membership: [189]

\begin{tabular}{|c|c|c|c|}
\hline Section & Condition & Amount & $\begin{array}{c}\text { Membership } \\
\text { Status }\end{array}$ \\
\hline 1 Legions & $\begin{array}{l}\text { Men. Legionaries: } \\
\text { authentic veterans of } \\
1914-18 \text { or the colonial } \\
\text { wars which followed. } \\
\text { Cadets (Aspirants): French } \\
\text { men who were too young } \\
\text { to fight in 1914-18 } \\
\text { (minimum age 20). }\end{array}$ & - 10 francs/year & $\begin{array}{l}\text { - Legionaries } \\
\text { - Cadets }\end{array}$ \\
\hline $\begin{array}{l}2 \text { Faisceau of } \\
\text { Corporations }\end{array}$ & $\begin{array}{l}\text { Men. Peasants, Farmers, } \\
\text { Working Men, } \\
\text { Shopkeepers, White } \\
\text { collar workers, } \\
\text { Technicians, Company } \\
\text { Directors. }\end{array}$ & $\begin{array}{l}\text { - } 10 \text { francs/year } \\
-25 \text { francs/year } \\
-100 \text { francs/year } \\
\text { - } 500 \text { francs/year } \\
+ \text { Monthly subscriptions of } 10 \\
\text { francs } 50 \text { centimes or according to } \\
\text { corporation. }\end{array}$ & $\begin{array}{l}\text { - Subscribing } \\
\text { Member } \\
\text { - Active member } \\
\text { - Benefactor } \\
\text { Member } \\
\text { - Founding } \\
\text { Member }\end{array}$ \\
\hline $\begin{array}{l}3 \text { Fascist Youth } \\
\text { (Zeunesses fascistes) }\end{array}$ & $\begin{array}{l}\text { Young Frenchmen aged } \\
\text { less than } 20 \text { years. }\end{array}$ & - 10 francs/year & \\
\hline 4 Civic Faisceau & $\begin{array}{l}\text { Frenchmen belonging to } \\
\text { none of the preceding } \\
\text { categories or not wishing } \\
\text { to join as such; French } \\
\text { women. }\end{array}$ & $\begin{array}{l}\text { - } 10 \text { francs/year } \\
-25 \text { francs/year } \\
-100 \text { francs/year } \\
-500 \text { francs/year }\end{array}$ & $\begin{array}{l}\text { - Subscribing } \\
\text { Member } \\
\text { - Active member } \\
\text { - Benefactor } \\
\text { Member } \\
\text { - Founding } \\
\text { Member }\end{array}$ \\
\hline
\end{tabular}

Tab: Conditions of membership.

\footnotetext{
${ }^{59}$ S. Kalman, The Extreme Right in Interwar France, op.cit. p.119; D. Sarnoff, 'In the Cervix of the Nation', op.cit.

${ }^{60}$ 'Faisceau des combattants', Leaflet n.5, 11 November 1925, CARAN, AN F7 13210.
} 
Women could thus join the Faisceau, and they contributed financially in the same way as the men in their Section. ${ }^{61}$ However, they could only join the Civic Section, which was to a great extent scorned by the movement's founders. As stated in a circular of November 1926 in the section covering Faisceau members' discipline, ' the Civic Faisceau is intended to group together members who for one reason or another, cannot or will not take part in effective action. This formation will thus play host to the eternally absent who provide us with no help'. ${ }^{62}$ Women are thus considered to fall into the same category as those Frenchmen who fail to qualify by their fighting capability or their profession as something more than the 'eternally absent', useless members of the organization.

The hyper-masculinism of the discourse is perfectly congruent with the Faisceau's organization. It is therefore in no way surprising to see that few women attended Faisceau meetings and were active there. The regular presence of communists or anti-fascist militants and the street fights which ensued also explain the masculine character of these meetings. Of the rare women who were present, we know little. As Daniella Sarnoff mentions in her thesis, when any mention is made of women at these meetings, only their number is given. Their social or professional affiliations are never mentioned, which is not the case for men, or their age.

One female figure does however emerge clearly, though: Countess Thibaut de Chasteigner. She is rather an exception. She is the sole women to figure in the Sûreté générale's memoranda about the Faisceau's leaders. Previously the doyenne of the royalist ladies of Périgueux, she is said to have convinced the former communist Mayor of the

\footnotetext{
${ }^{61}$ We have not found the financial discrimination toward women described by Sarnoff. (See 'In the Cervix of the Nation'.)

${ }^{62}$ Copy of Typescript Circular, September 20 1926, CARAN, AN F7 13210.
} 
city to join the Faisceau ${ }^{63}$. She was a war widow and the mother of four children. According to information gathered by the Périgueux Police Superintendant (Commissaire de police), she was wealthy, like Trilby, the apologist for the Croix de Feu. She is the only female figure to emerge from the rare women active in the Civic Sections. From the Catholic aristocracy, she stood out because of her conduct, which was judged in the Sûreté report to be indecorous: 'she is considered to be involved in militant politics in favour of fascism and women's suffrage. She has royalist, reactionary and clerical opinions. She is the Chairwoman of Action Française' ${ }^{64}$ The police report adds that the former communist Mayor, Delagrange, 'is rightly or wrongly said to have been the lover of the Countess, something which could not be proved. (...) However, it is proved that they were on the best of terms together and it is certain that Delagrange's joining the Faisceau is the result of the ascendancy which the Countess of Chasteigner had gained over him'. ${ }^{65}$ [190] For this reason, the Bishop of Périgueux removed the Countess from her functions in the Association of Lady Patrons (Association des dames patronnesses), thus depriving her of that Catholic social life in which the leading female figures of extremeright and right-wing associations were expected to participate.

Her story thus resembles that of those defectors from Action française, the monarchist league, who went over to the Faisceau at the time of its foundation. The Faisceau had been founded by Georges Valois, a former member of Action française, and was in competition with that league. Her political career as leader of the committee of royalist ladies is close to that of other male members of the Action française leadership. The various resources at her disposal, both material and social, especially the 'capture' of the

\footnotetext{
${ }^{63}$ Commissariat général de Périgueux, 'Légion-Faisceau', Périgueux, 7 April 1926, CARAN, AN F7 13208.

${ }^{64}$ Commissariat général de Périgueux, 'Légion-Faisceau', Périgueux, 7 April 1926, CARAN, AN F7 13208, p.2.

${ }^{65}$ Commissariat général de Périgueux, 'Légion-Faisceau', Périgueux, 7 April 1926, CARAN, AN F7 13208, p.2 ; Anonymous, typed memorandum March 24 1926, CARAN, AN F7 13210.
} 
Communist Delagrange, enabled her to achieve a position more significant than that of other women in this movement, where they were confined to the Civic Sections. The existence of this exceptional personality fails to mask completely the fact that in this league, women were largely relegated to secondary roles. The original matrix of war veterans, pronounced hyper-virility and the significant paramilitary dimension of the group as well as the opposition between a modernising line and a line clearly marked to a greater extent by conservatism all contributed towards strengthening the gendered hierarchy of the organization and towards marginalizing women within the movement.

\section{Militancy and Complementarities: the Jeunesses patriotes and the National Union for Women's Suffrage.}

The other leagues, in contrast, seem to have espoused the conservative model of a sexual division of militant activities instituted within conservative groupings since the beginning of the last century. ${ }^{66}$ Women were therefore made responsible for [191] social action and work associated with the functioning of the masculine political organization, as in modern political parties in other countries. ${ }^{67}$ The Feunesses patriotes, who saw the light of day in December 1924, originated in a transformation of the League of Patriots (Ligue des patriotes), a nationalist league which saw its apogee at the end of the nineteenth century, and of the reaction against the demonstrations which accompanied the transfer of the socialist Jean Jaurès' ashes to the Pantheon. It was transformed into the Feunesses Patriotes in December 1924 under the leadership of Pierre Taittinger, the parliamentary deputy for Paris. Following incidents in the rue Damrémont in Paris, in the course of which clashes between Young Communists and JP members caused several deaths among the latter, the League became radicalised. It was made up of combat troops, the Mobile

\footnotetext{
${ }^{66}$ M. Della Sudda; La Citoyenneté avant le vote (Paris : Belin, 2012).

${ }^{67}$ P. Vervaecke, 'Dieu, la Couronne et l'Empire. La Primerose League (1883-2000)' (PhD dissertation, Université de Lille 3, 2003) ; J.V. Gottlieb, Feminine fascism, op.cit.pp.65;69-72
} 
Groups (Groupes mobiles), carefully selected male 'elite troops' who were responsible for the League's security and crowd control. The Phalanges universitaires (University Phalanxes), recruited from young students, were able to accept young women among their ranks. Female Phalangeardes were distinguished from members of the women's sections by their uniform and their age. In Lyon, the women's Phalanges were also open to young female wage earners. As Madeleine Billard, the leader of the Lyon women's Phalange states, 'the women's Phalange in Lyon included not only students but also numerous female workers' ${ }^{9}$. Their activities were directed towards social action and propaganda. ${ }^{69}$ They thus took charge of the distribution of assistance to the unemployed either autonomously or with the women's sections (Sections féminines) and did not engaged street fightings. ${ }^{70}$ Finally, the women's sections, open only to women, were principally responsible for social action and mutual assistance. In 1928, the JP claimed 3000 members in the Paris Women's sections, while the Phalangeardes of the same region numbered 4,000.71 Although reference is much more frequently made to women in the context of political meetings than for the Faisceau, they nevertheless did not have the same status as men within the organization.

Nonetheless, social action was presented in the columns of the National newspaper as a shop window for the Jeunesses Patriotes. The Préventorium, located on the Ile de Ré near La Rochelle, was a model healthcare institution, entirely financed by the JP, which was put forward to show the association's respectability in order to enlarge the voters support. 'The masterpiece of the Jeunesses Patriotes, the women's sections and of admirable

\footnotetext{
${ }^{68}$ M. Billard, 'Phalange féminine', L'Alerte, Bulletin de liaison des Jeunesses Patriotes de la région lyonnaise, November 1935, p.2.

69 'Phalanges universitaires-Phalange féminine', L'Alerte, Bulletin de liaison des Jeunesses Patriotes de la région lyonnaise, May 1936, p.2.

${ }^{70}$ L'Alerte, Bulletin de liaison des Jeunesses Patriotes de la région lyonnaise, January 1935, p.2.

${ }^{71}$ Jeunesses Patriotes, 'Les Jeunesses Patriotes - Vers la Rénovation française', leaflet, CARAN, AN F7 13235.
} 
women', ${ }^{72}$ this institution provided care for children from needy families. A testimony to the strong links which united the JP's leaders to Catholic elites, it was directed by a Red Cross nurse, $\mathrm{M}^{\mathrm{lle}}$ Yvonne Roques ${ }^{73}$ and presided over by Pierre Taittinger's second wife, Anne Marie Pulchérie Mailly. A war widow, she was actively engaged with social action and also took part in the activities of the National Union for Women's Suffrage. She was the UNWS's head of propaganda in the Paris area, ${ }^{74}$ She was also a member of the National Committee of the National Federation of Women (Fédération nationale des Femmes) from the time of its creation in $1928 .^{75}$ This female-based party was opposed to those feminists close to left-wing parties. It called for women's suffrage and their right of access to the professions and saw itself as the defender of women's interests in the political field.

In the course of normal political activism, with the exception of Marie-Thérèse Moreau, the national chairwoman of the women's sections, women rarely took the floor in general meetings of the JP. ${ }^{76}$ Marie-Thérèse Moreau, an exceptional figure, nevertheless illustrates the ambiguities of the view taken of gender taken by this kind of league. When she took up her duties with the JP, she was a lawyer at the Paris bar, and was one of a pioneering generation of women who were admitted to the French legal profession opened to women only in $1900 .{ }^{77}$ She became politically involved in the National Union for Women's Suffrage, a Catholic suffragist organization founded in 1920 to claim the

\footnotetext{
${ }^{72}$ Jeunesses Patriotes, Ce que sont les Jeunesses Patriotes: leur programme, leur oeuvre, (Paris, Centre de propagande des Jeunesses patriotes, 1935), p.11.

${ }^{73}$ Revue des établissements \& des cuvres de bienfaisance : paraissant le 15 de chaque mois, 52 (1936), p.381.

${ }^{74}$ 'Pierre Taittinger', Dictionnaire biographique des parlementaires de la Seine, p.555.

${ }^{75}$ 'Fédération nationale des femmes, 42 bis $B^{\mathrm{d}}$ de Latour-Maubourg, Paris', leaflet, Archivio Segreto Vaticano (ASV), Seg. di Stato, 1934, rubr. 325, fasc.2, ff.45.

${ }^{76}$ C.Koos\&D.Sarnoff, op.cit., pp.176-178.

${ }^{77}$ See also S.L. Kimble, 'No Right to Judge: Feminism and the Judiciary in Third Republic France', French Historical Studies, 31:4 (2008), pp.609-641.
} 
right to vote and to defend the Catholic social order. ${ }^{78}$ She held responsibilities at national level in this women's organization at the same time as with the JP. Daniella Sarnoff emphasizes that this multiple membership strengthened the [192] JP's position in favour of women's suffrage. ${ }^{79}$ This position as a 'broker' between different conservative organizations, ${ }^{80}$ was not only shared by Marie-Thérèse Moreau, but also by other leaders of the National Federation of Women, a political formation which emerged from a break with the National Federation for Women's Suffrage, which was judged too moderate by Aimée Bazy. One thus finds at the head of these organizations the wives or close associates of JP and Republican Federation (Fédération Républicaine) leaders. ${ }^{81}$ Her trajectory illustrates the fact that Catholicism provided some women with dispositions that were easily convertible in a political know-how in right-wing and farright movements.

Most right-wing organizations were in favour of women's suffrage for strategic and religious reasons. Right-wing and extreme-right parties accepted the consequences of their close relationship with the Catholic Church, a defender of women's suffrage since 1919. Moreover, most political leaders saw the female electorate as supporting rightwing and conservative parties, an assessment confirmed by initial patterns of female

\footnotetext{
${ }^{78} \mathrm{UNVF}$, Ce que les femmes demandent, ce qu'elles ont obtenu, (Meulan, Firmin Rocher, 1923), ASV, Affari ecclesiastici straordinari (AES), Francia 643 PO, vote des femmes. She was a member in 1926 and was still a member of the Management Committee (Comité de direction) in 1931, 'Union française pour le vote des femmes', leaflet, ASV, Arch. Nunz.Parigi, b.454, fasc.552, ff.172.

${ }^{79}$ D. Sarnoff, 'Interwar Fascism and the Franchise: Women's Suffrage and the Ligues', Historical Reflections, 34:2 (2008), pp.113-117.

${ }^{80}$ D.McAdam, S.Tarrow and C.Tilly (eds.) Dynamics of Contention (Cambridge:Cambridge University Press, 2001): "We define [brokerage] as the linking of two or more previously unconnected social sites by a unit that mediates their relations with one another and/or with yet other sites. Most analysts see brokerage as a mechanism relating groups and individuals to one another in stable sites, but it can also become a relatio-nal mechanism for mobilization during periods of contentious politics, as new groups are thrown together by increased interaction and uncertainty, thus discovering their common interests", p.26; In this sense, the very presence of women as M.T. Moreau could also have contributed to put women's political right on the agenda.

${ }^{81}$ M. Della Sudda, 'Right-wing Feminism and Conservative Women's Militancy in Interwar France', S. Kalman (Ed) Proceedings of the conference 'Les Droites en France dans l'entre-deux-guerres', to be published.
} 
voting. Nevertheless, this female suffrage did not form part of a set of egalitarian or individualistic demands: women were not being asked to vote as individuals or as citizens equal to men. As stated in the bulletin of the Catholic association, 'the organization of the franchise is defective. It is based on the principle of egalitarianism. This system is vicious's2, because it does not represent the good elements of the nation such as the families or the producers of wealth. Thus, women were called out to vote in order to defend their interests as mothers, to instil some morality into political life, strongly marked as it was by scandals, and to renew a discredited political system. As Simone Bacque, the secretary of the Lyon women's section, wrote in the columns of l'Alerte,

'Let us claim the right to vote to defend our interests as women, mothers, wives, and workers; to protect our children, safeguard the integrity of the family, and maintain respect for basic freedoms. Let us not disdain the instrument which can enable us to defend our homes and participate alongside men in the destinies of France'83

Suffrage was thus a means and not an end to achieve an egalitarian society. From this perspective, the family vote was seen by the JP as complementary to female suffrage. Since the homeland (la Patrie) was thought of as one large family, it was also necessary to strengthen each of the basic units of society by granting an additional vote to heads of family. The Feunesses Patriotes thus advocated a family suffrage which would compensate the increased weight given to single individuals at elections by giving additional voting rights to Heads of Family. ${ }^{84}$ The contradiction of individualistic suffrage and familial one is [193] resolved in an electoral system based on the assumption that each single entity must not have a weight according to its social utility.

\footnotetext{
${ }^{82}$ T. Mainage, 'Conférence sur le vote des femmes', Echo de la Ligue patriotique des Françaises, April 1918, pp.1-2.

${ }^{83}$ S. Bacque, 'La Française doit-elle voter ?', L'Alerte, bulletin de liaison des Jeunesses Patriotes de la région lyonaise, 41, May 1937, p.2.

${ }^{84}$ D. Sarnoff, 'Interwar Fascism and the Franchise. Women's Suffrage and the Ligues', Historical Reflections, 34:2 (2008), pp.113-116.
} 
Gender thus structured the JP's organization differently from that of the Faisceau. The extent of the on-going social crisis in part explains the way the organization was to constitute social issues as a field of female action for the Phalangeardes and the women's sections. Recruiting patterns in the JP also show how activism complemented itself, whether in the form of female JP leaders or of the wives of leading members of the UNVF or of the National Federation of Women. There intermediary position favoured the JP's adoption of the cause of women's suffrage and of women's access to the professions. This close relationship between the catholic suffragist organizations and the JP not only ensured a flow of female recruits to the JP but provided a shop window of respectability against their detractors.

The Croix de Feu and the Parti social français: the internalization of the sexual division of militant activity and the Catholic matrix

Can this complementary positioning be found in that other mass organization which engaged, not in 'politics first' 85 but in 'social matters first'? In his pioneering article, Kevin Passmore studied in minute detail the transformation and composition of the social sections of the Croix de Feu and PSF. The Croix de Feu was created in 1927 by Maurice d'Hartoy. They were primarily an association of war veterans who found in it the comradeship of the trenches and which crystallized dissatisfaction with the parliamentary regime. In 1928, a corps of war veterans, the Briscards, joined them. A turning point was reached when Colonel François de la Rocque was called upon to preside over the association at the request of Field Marshal Lyautey and Jacques Fayolle. There followed a modernising reorganization and redevelopment of the organization, which claimed 400,000 members in 1935. The National Volunteers

\footnotetext{
${ }^{85}$ The slogan 'Politics First' was that of the Action française. This attitude was one of the causes of the condemnation of Action française by Pope Pius XI in 1926. Colonel de la Rocque, a practising Catholic, saw himself as following the papal line.
} 
(Volontaires nationaux) were set up in 1933 as a paramilitary organization within the movement, taking up the baton from the war veterans and ready to seize power if need be and to confront Communist militants.

As Passmore reminds us, from this perspective the safety of the country was in the hands of veteran soldiers and more generally, of men. As a result of this, women had only a secondary position in the movement's symbolic and organizational hierarchy. It was only in November 1934 that a women's section was set up. The principal change took place in November 1934, when social action sections were set up within the Croix de Feu women's sections. Each local section appointed a social action delegate who was responsible for cloakrooms, social outreach and supervision of children's activities. ${ }^{86}$ After the dissolution of the Croix de Feu following the coming to power of the Popular Front in 1936, the women's sections briefly interrupted their activities before being renamed as civic action sections. Social action sections were reconstituted within this group. These civic sections, to which social action now devolved, constituted an essential element within the party's social policy.

J.-P. Thomas emphasizes their importance for the political careers of right-wing female politicians after the war, such as Marcelle Devaud, who having passed through the ranks of the PSF and then the Association of Free Frenchwomen [194] (Association des Françaises libres) became Vice-President of the Senate following the Général De Gaulle. ${ }^{87}$ The PSF attracted a significant number of women, an exceptional feat for political parties in France; in the Paris region, one-third of members were women ${ }^{88}$. Women formed $31.5 \%$ of the membership of the 'red districts' of Montreuil, a working-class city to the

\footnotetext{
${ }^{86}$ K. Passmore, 'Planting the Tricolore', p.824.; L.L. Downs, , 'Each and every one of you must become a chef'. Toward a Social Politics of Working-Class Childhood on the Extreme Right in 1930's France', Journal of Modern History, 81:1 (2009), pp.1-44.

${ }^{87}$ J.-P. Thomas, 'Le Parti Social français (1936-1945), op.cit.p.117.

${ }^{88}$ J.-P. Thomas, 'Le Parti Social français (1936-1945). Une expérience de parti de masses et la préparation d'une relève', Annales de Bretagne et des Pays de l'Ouest, 109:3 (2002), pp.110.
} 
east of Paris ${ }^{89}$. In Nantes, in Brittany, the monthly meetings of members even had to be divided up in order to make room for women who in 1937 represented at least $40 \%$ of the section. In contrast, in the North (Fédération $d u$ Nord), they are only estimated to have formed $10 \%$ of the membership. The social background of these female activists shows on the one hand that a number of these women were wage-earners, with jobs in occupations which were feminized between the wars: shorthand typists, superintendants, shop workers. They thus belonged to the lower middle class and were relatively independent financially ${ }^{90}$. Passmore had observed the presence of female wage earners but his corpus focussed more on housewives or women whose occupation was unknown $^{91}$. He also drew attention to the significant presence of nurses, superintendants, social workers, thus highlighting the early professionalization of social activism within the movement.

This strong female presence leads us to nuance analyses of male domination and women's position of submission or as victims on the one hand by identifying a form of constrained agency within the movement, and on the other hand by reassessing the extent to which women were assigned to the domestic sphere. Thus, the rhetoric of home and family duties is to be understood in a wider sense, which confers a maternal dimension on female activism in social action and which forms part of an extension of female tasks. Far from being the hallmark of extreme-right organizations, this gendered vision of the social world was held by all conservative organizations, especially by Catholic women's associations which at this time had more than two million members. If we compare practices within the Croix de Feu to those within the Frenchwomen's League for Catholic Action (Ligue féminine d'action catholique française), we notice the close

\footnotetext{
${ }^{89}$ J.-P. Thomas, 'Les effectifs du Parti Social Français', Vingtième Siècle. Revue d'Histoire, 62 (1999), pp.61-83, p.66.

${ }^{90}$ J.-P. Thomas, 'Les effectifs' op. cit.

${ }^{91}$ K. Passmore, 'Planting the Tricolore', op. cit., pp.832-834.
} 
relationship between the directing techniques used, as well as between social activities not only dispensaries, cloakrooms and soup kitchens, but also holiday camps, nurseries, etc.

A good illustration of the 'conversion' of social activism know-how from Catholic movement into the political league/party could be found in the trajectory of Marie Diémer. The political career of a Marie Diémer, the founder of the French Girl Scouts, is in this respect revealing of a specifically feminine catholic element within the Croix de Feu. Marie Diémer's origins were in the Vosges bourgeoisie. She was born in 1877 to a Protestant family at Epinal. Just before the Great War she participated in the founding of the French Association of Visiting Nurses (Association des infirmières visiteuses de France). In particular, she trained personnel for the Red Cross and founded one of the first Social Schools (Ecoles sociales) at Levallois Perret on the outskirts of Paris ${ }^{92}$. During the war, in June 1917, she was one of the founders of the School of Female Factory Superintendants (Ecole des surintendantes d'usine). Its purpose was to train women to take up posts as 'social superintendant directors' (directrices surveillantes sociales) in arms factories, who [195] were considered to be 'godmothers of social peace'. ${ }^{93}$ Her conversion to Catholicism in 1924 marked an important turning point. This occurred shortly after her encounter with scouting. This experience of leadership and her contribution to the professionalization of management and care activities were two fundamental resources which would rapidly contribute to female activist know-how in the Croix de Feu and the PSF, especially with regard to children. ${ }^{94}$ Strangely forgotten in the French historiography of scouting and girl guiding ${ }^{95}$, this membership of the Croix de Feu gives a

\footnotetext{
${ }^{92}$ E. Diebolt (Ed), Dictionnaire biographique. Militer au XXe siècle. Femmes, féminismes, Églises et société, (Paris: Houdiard, 2008).

${ }^{93}$ L.L. Downs, 'Les Marraines élues de la paix sociale? Les surintendantes d'usine et la rationalisation du travail en France, 1917-1935', Le Mouvement Social, 164 (1993), pp.53-76.

${ }^{94}$ K. Passmore, 'Planting the Tricolore', art. cit.; LL. Downs.

${ }^{95}$ E. Diébolt ne la mentionne pas. L'ouvrage de M.-T. Cheroutre ne lui consacre que quelques lignes, $\mathrm{cf}$.
} 
more general meaning to her activity. Activity in the Croix de Feu and PSF was the continuation of a female Catholic social activism which found in this secular organization an opportunity for mass action.

At the conclusion of this historiographic review, various elements emerge. Extreme-right and fascist organizations recruited widely and women represented a variable proportion of their memberships. The resonance of the war veteran profile mediated by a highly marked and violent paramilitary identity seems to have discouraged the presence of women. In contrast, once the leagues sought to conquer the masses through social action, women became an essential buttress of this policy. As regards female activists themselves, it would appear that these were mainly women from the middle classes and petty bourgeoisie, sociologically very close to the composition of the same associations as regards men. Perhaps what better marks the difference between male and female activists in these associations is the multiple membership of Catholic networks that can be seen: in the JP, where masculine political elites are better represented, one finds memberships of more political organizations such as the UNVF or the National Federation of Women. In the Croix de Feu, it seems that the female membership pool was provided by Catholic youth organizations. According to current research, it would appear that women participants in street fights constituted only a minority phenomenon and the sources are at present silent on this subject. The violence characteristic of fascist movements, including Catholic action movements in Germany and Italy, seems to have passed over female activists in the organizations which we have been able to study. More than a uniquely fascist femininity, we are faced with a continuum between the various right-wing and extreme-right organizations, for which the Catholic matrix, both 
from an ideological and an organizational point of view, remains a fundamental characteristic. Taking this incremental path into account enables us to understand the massive support given by women and conservative women's organizations to the Vichy regime and how the 'female social elite' rapidly gained the favour of the authoritarian state to promote its 'eternal femininity'. 